\title{
IdeAs
}

Idées d'Amériques

$16 \mid 2020$

Les marges créatrices : intellectuel.le.s afrodescendant.e.s et indigènes auX Amériques, XIX-XXe siècle

\section{Mary Church Terrell (1863-1954): A Black Woman Pioneer Historian: From the Margin to the Center Stage}

Mary Church Terrell (1863-1954): Historienne africaine américaine pionnière : de la marge au centre

Mary Church Terrell (1863-1954) : pionera historiadora afro americana, de la margen al centro

Fatma Ramdani

\section{OpenEdition}

1 Journals

Electronic version

URL: http://journals.openedition.org/ideas/9327

DOI: 10.4000/ideas.9327

ISSN: 1950-5701

Publisher

Institut des Amériques

\section{Electronic reference}

Fatma Ramdani, « Mary Church Terrell (1863-1954): A Black Woman Pioneer Historian: From the Margin to the Center Stage », IdeAs [Online], 16 | 2020, Online since 01 October 2020, connection on 18 October 2020. URL : http://journals.openedition.org/ideas/9327 ; DOl : https://doi.org/10.4000/ideas. 9327

This text was automatically generated on 18 October 2020 .

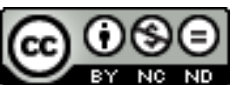

IdeAs - Idées d'Amériques est mis à disposition selon les termes de la licence Creative Commons Attribution - Pas d'Utilisation Commerciale - Pas de Modification 4.0 International. 


\title{
Mary Church Terrell (1863-1954): A Black Woman Pioneer Historian: From the Margin to the Center Stage
}

\author{
Mary Church Terrell (1863-1954): Historienne africaine américaine pionnière : de \\ la marge au centre \\ Mary Church Terrell (1863-1954) : pionera historiadora afro americana, de la \\ margen al centro
}

Fatma Ramdani

\section{Introduction}

1 "I want to write. I must write. Everything seems to be telling me that this is my calling, my sacred duty almost". ${ }^{1}$ These were Mary Church Terrell's notes in her October $29^{\text {th }}$, 1888 diary entry as a twenty-five-year-old young African American graduate of Oberlin, the first American college to admit women. She was travelling in Europe to improve her command of foreign languages. As one of the best-educated women of her race, she felt almost obsessed by the desire to achieve something meaningful before dying (Wilks J.M., 2014: 14,16). ${ }^{2}$ One of the recurrent themes of her French diary is her duty to write and her early political consciousness of her responsibility towards her community. Her dream became reality. With a sixty-year-long career (1892-1954) as a black woman activist and leader, she penned dozens of articles, mainly in the black press, both North and South, a few in the white press, and a number of short stories. At the age of seventy-seven, she published her autobiography at her own expense. Scant attention has been given to Mary Church Terrell's work as a historian and popularizer of African American women's history to date. Despite all her activities as a black woman leader, in their 1982 anthology Black Leaders in The Twentieth Century, one of the best-selling 
African American history titles, John Hope Franklin and August Meier acknowledged that Mary Church Terrell was among the dozen leaders they had decided not to select for their final work (Dagbovie P.G., 2015: 71). ${ }^{3}$ Even after African American history became a legitimate field of studies in the wake of the Civil Rights Movement, black women continued to remain at the bottom within the profession in terms of hierarchical status.

2 This article seeks to give Mary Church Terrell a statutory place as a historian. Drawing on her autobiography, it will first look at her life trajectory with the view of highlighting her acute awareness of the different functions of history and in particular the place of black women in American history through her work as a black woman leader. It will then examine her career as a journalist. Despite receiving countless rejections from newspaper and journal editors, she never gave up and wrote a number of essays. The second part will then examine four articles which showcase Mary Church Terrell's pragmatic approach to history while aiming at offering a new interpretation on salient issues in post-Reconstruction and Jim Crow America, such as lynching viewed from the perspective of a black woman. It can be argued that Mary Church Terrell, as both witness and actor, forced her way into the profession as a selfproclaimed historian. Finally, this article will focus on Mary Church Terrell's selfpublished autobiography, a detailed and compelling testimony of a black woman living in segregated America. I will demonstrate that her pioneering audacious endeavor, as a black intellectual writer, lay the groundwork for African American history and was a successful attempt at moving black women to a central place in American historiography.

\section{An exceptional life trajectory in the service of history}

Mary Church Terrell's activism spanned over six decades from the Post-Reconstruction era to the 1954 Brown $v$ Board of Education decision. Born in 1863 in Memphis, Tennessee, of slave-born parents, she had an extraordinary life for a black woman of her time, combining public engagement and private family life. Her father became a billionaire in the South as a real estate agent in Memphis and her mother was a successful businesswoman who owned a hair-saloon in Memphis and then in New York. After her parents' divorce, she studied in white schools (Antioch Model School at Yellow Spring in Ohio, Oberlin High School and then Oberlin College). Although she recounts happy days and the openness of her classmates, as a child and then as a young woman studying in white schools, traumatic experiences shaped her racial and gender identity. Amongst these experiences is the time when a conductor asked her to change seats to the coach she "belonged" to when she was five years old, the mockery of her classmates because of her black face, the day when, during a history class on the Emancipation Proclamation, she understood the inferior status of her slave ancestors and the reason why she had been asked to play the role of the black servant, which she refused to perform (Terrell M.C., 2005: 46, 51-53). How did Mary Church Terrell embrace her privileged life to become a symbol and spokesperson for her community and how did it influence her awareness of the significance of history as a political tool for selfempowerment and social change?

Her college years at Oberlin offered new openings to Mary Church Terrell. She took Latin and Greek classes. Keenly interested in literature, she started writing poetry and 
essays and she repeatedly expressed her wish to write fiction. She became involved in the editorial board of the Oberlin Review. During her freshman year, thanks to Josephine Bruce, the wife of Senator Blanche Bruce (Republican, Mississippi), she had the opportunity to meet Frederick Douglass for whom she had a deep admiration (Terrell M.C., 2005: 83). Her early life as a pupil and a student navigating her way around a predominantly white world, a minority within the minority, together with all these small incidents, reminders of her idiosyncratic status, pushed her to excel and to hold high "the banner of her race" (Terrell M.C., 2005: 93).

After graduating in the classics from Oberlin in 1884 - she became one of the first African Americans to earn a college degree - , she taught for a year at Wilberforce University, a historically black college, and moved to Washington where she pursued her teaching career at M. Street Colored High School. ${ }^{4}$ She then undertook a two-year trip to Europe to study German and French..$^{5}$ In 1891, after her return to the United States, she married Robert Terrell, a cum laude graduate of Harvard and the first black judge appointed to the Municipal Court of the District of Washington. ${ }^{6}$ In 1892, the lynching of Tom Moss, a long-life friend who was also a friend of Ida B. Wells ${ }^{7}$, was the catalyst for her activism. It was the beginning of her involvement in black women's clubs.

6 The 1890-1895 period was marked by a proliferation of black women's clubs (Jones B.W., 1982: 20). Doubly marginalized by white women's racism and black men's sexism, black women started to unite around self-help organizations to both advocate for their rights and improve the status of their community as a whole. In 1892, Mary Church Terrell became the Chairwoman of the Educational Committee of the National Colored Women's League, based in Washington D.C. ${ }^{8}$ In 1895, Josephine St. Pierre Ruffin, who had started the Women's Era Club in Boston around 1892, decided to convene a national convention attended by 100 women from 20 clubs across the United States as an answer to the attack on black women by James Jacks, the president of the Missouri Press Association. ${ }^{9}$ In a letter, he challenged the respectability of African American women, referring to them as thieves and prostitutes. The convention marked the launching of the National Federation of Afro-American Women, which a year later in 1896 united with the Colored Women's League to become the National Association of Colored Women (NACW). In the same year, the 1896 Plessy $v$ Ferguson Supreme Court decision, which legalized segregation, galvanized black women into action and propelled Mary Church Terrell's career to national and international recognition.

7 The founding meeting of the NACW was attended by public black female leaders, known as race women, among whom were Harriet Tubman. Francis E.W. Harper, Ida B. Wells Barnett and Margaret Murray Washington. Mary Church Terrell was appointed as its first president. These women strongly believed that they needed to "band together" against the "barbarities and abuses" degrading black Americans, and black women in particular. ${ }^{10}$ The fact that African American women founded their own organization fourteen years before the creation of the National Association for the Advancement of Colored People, shows that they shrewdly understood that black women had a tremendous responsibility and opportunity to speak on their own behalf and offer race leadership. ${ }^{11}$

8 Aware of her elite status and proud of her intellectual background, Mary Church Terrell adopted W.E.B. Du Bois's ideology of the Talented Tenth, defined as the African American intellectuals who were responsible for elevating their race (Watson M., 2009: 
67). ${ }^{12}$ In particular, as some of her contemporary African American women educators in Washington D.C., such as Julia Anna Cooper, she viewed herself as a moral leader, a voice for the more disadvantaged colored women, and a knowledge transmitter. The NACW's motto as stipulated in its Constitution "Lifting as we Climb" is symbolic of the mission Terrell assigned herself. She declared: "In no way could we live up to such a sentiment better than by coming into closer touch with the masses of our people... So, that, if the call of duty were disregarded altogether, policy and self-preservation would demand that we do go down among the ties of race and sex, and put forth every possible effort to uplift and claim them". ${ }^{13}$ Even though this tone might seem condescending, it cannot be denied that, during her two tenures as president of the NACW (1896-1900), Mary Church Terrell helped launch a series of initiatives in the areas of education and social welfare with the opening of day care nurseries, schools of domestic science, settlement houses and sanatoriums. As an example, she printed in pamphlet form the address "The Progress of Colored Women" she first delivered at the National American Women's Suffrage Association in Washington in February 1898. She sold the pamphlet to visitors and attendees to raise funds for kindergartens. Such initiatives show that, despite her privileged status, she was quite aware of and interested in the problems confronted by black working-class married women and that she endeavored to improve their lot. As a staunch supporter of women's suffrage, whenever talking before white women's audiences, she explicitly highlighted the progress made by colored women despite the fact that "not only are colored women with ambition and aspiration handicapped on account of their sex, but they are everywhere baffled and mocked on account of their race." Mary Church Terrell strongly believed in the maternalistic vision of black womanhood, advocating for "homes, more homes, better homes, purer homes." She was convinced that the home and the women's virtue were the pivotal forces for the advancement of the community.

Mary Church Terrell's European trips were also transformative experiences and boosted her self-confidence. Her French diary, which spans from August 1888 to October 1889, sheds light on her particular interest in history and more specifically in female writers writing about fellow women. She liked reading the French press and even translated articles on history or women. For example, she had read an article in the Revue politique et littéraire, "The Participation of France in the Establishment of the Independence of the United States," and another entitled "The Role of the Woman" in Le Petit Journal. She sent her translations to American newspapers for publication (Wilks J.M., 2014: 16). She was acquainted with the works of Mme de Sévigné and George Sand. of the latter she had read Histoire de ma vie. We can surmise that she was sensitive to women's writings because as an educated black woman, she had a good knowledge of the long tradition of intellectual production of black women writers (Waters K. and Conaway C.B., 2007: 3).

In addition, travelling through France, Switzerland, Italy and Germany gave her a better grasp of the abnormality of the Race Problem ${ }^{14}$ in America. She came into contact with the pervasive racist mentality of white Americans who lived in Europe and contrasted their attitude with the more egalitarian one of her European hosts towards her. But most significantly, when, as a suffragist and a peace activist, she was part of the American delegation at the 1904 International Women's Council in Berlin and at the 1919 Women's International League for Peace and Freedom in Zurich, she felt invested with a huge responsibility as she was representing, "not only the colored women of my own country but, since I was the only woman taking part in the International Congress 
who had a drop of African blood in her veins, I represented the whole continent of Africa too" (Terrell M.C., 2005: 238-247, 372). ${ }^{15}$ At these two international gatherings, Mary Church Terrell delivered two acclaimed speeches in German. She starts her Berlin speech focusing on her personal and unique story as the child of former slaves "if it had not been for the War of Rebellion, my friends, which resulted in victory for the Union forces in 1865, instead of addressing you as a free woman tonight, in all human probability I should be on some plantation in one of the southern states of my country, manacled body and soul in the fetters of a slave," to then shift to the progress of all African American women in different professional fields (education, business, arts...) despite the tremendous obstacles confronting them, progress she qualified as a "veritable miracle of our times". She followed in Fannie Barrier Williams's footsteps, one of the six African American women addressing the first quinquennial International Congress of Women held in Chicago in 1893 to coincide with the World's Columbian and International Exposition and at which she gave her notable speech "The Intellectual Progress of the Colored Women in the United States since the Emancipation Proclamation" (Rief M., 2004: 204). As an internationalist, Mary Church Terrell developed a comparative perspective on the race issue embracing Pan-African ideology. She was quite aware of the historian Augustus Rogers' work and praised him for the "untiring efforts you have made to get the details of the feats of colored men and women in the development of the politically cultured life of many countries before the world. Everywhere those who hate the colonial and African colored peoples have tried to completely hide or distort or emasculate their history..." (Asukile T., 2010: 340). Such a quote shows that she strongly pushed for the dissemination of black history, including black women's history.

11 Another aspect of Mary Church Terrell's attitude to history as a clubwoman leader is her involvement in activities which sought to promote the study of the history of black people. Once established in Washington after her relatively late marriage at 28 , she attended the weekly meetings of the Bethel Literary and Historical Association, which was founded in 1881 and which constituted a special venue for male and female intellectuals to speak on topics pertaining to African American history and society (Terrell M.C., 2005: 442). In 1892, she became the first black woman to serve as the president of its executive board and held that position for eleven years. In 1895, she was the first black woman appointed as a member of the Board of Education in the District of Columbia, mainly thanks to her connections in Washington. The Board of Education was then made up of four white and two colored men and two white women. Among the members, she was the only one to have ever taught in the public schools of the District of Columbia (Terrell M.C., 2005: 165). During her tenure, she introduced a resolution to honor Douglass Day in public schools. Like most black clubwomen leaders, she embraced the work of commemoration, a symbolic measurement of black progress. As a clubwoman, within the NACW, as early as the 1920s, she helped sponsor educational programs to document black history. Members of the NACW developed plans to create an archive center and hired Dr. Charles Wesley, a young black historian, to write their history (Bracey J.H., and Meier A., 1994: 14). In 1922, their efforts led to the restoration and preservation of the Cedar Hill House of Frederick Douglass in Washington D.C. (Des Jardins J., 2000: 271). ${ }^{16}$ At that time, Mary Church Terrell was a founding member of the International Council of Women of the Darker Races (ICWDR) whose main objective was the "dissemination of knowledge of people of color so that the world can better appreciate their history and accomplishment." ${ }^{17}$ Mary Church 
Terrell's leadership role within the NACW and the ICWDR drove her to advocate the teaching of African American achievements and racial pride as a tool of selfempowerment for blacks and of consciousness-raising for whites. Finally, her influential network also included Carter Woodson who listed her among the associate editors of the Journal, so impressed was he by her career. ${ }^{18}$ She contributed pieces in the first several volumes of The Journal of Negro History, one of which was on the history of black high schools in Washington (Terrell M.C., 1917). ${ }^{19}$ She was a regular subscriber and did not hesitate to give substantial financial contributions when Woodson appealed to his readers to rescue the journal (Miller S.M., et al., 1976). ${ }^{20}$

12 As an intellectual black woman leader, Mary Church Terrell wanted to leave an imprint of her work for future generations. She lectured relentlessly throughout the South and had many of her lectures covered by the black press in the United States and her international lectures by the English press. In her diary, she explained that she kept articles about herself in a scrapbook. It was essential that she preserved her own archives and her comments as a record of women race leaders. (Quigley J., 2016: 56). Later in 1939, Mary McLeod Bethune, after being approached by Mary Beard to work for the establishment of a World Center for Women's Archives, launched the National Archives for Black Women's History (Henry L.J., 1981: 257). ${ }^{21}$ Mary Church Terrell, who was then part of the archives committee of the NCNW set up by Mary McLeod Bethune and Dorothy Porter, was appointed as the National Archives' historian. An intellectual and a social activist, Mary Church Terrell was also a history practitioner (Dagbovie P.G., 2015: 6). In the same way as many of her contemporaries, she resorted to the press to challenge the racist historical discourse and the demeaning stereotyping of her ostracized race (Logan R.W., 1954: 240).

\section{Mary Church Terrell: the self-proclaimed historian}

In 1982, Gloria Wade-Gayles, the scholar who looked at the historiography of the black women journalists, commented that only one article listed Mary Church Terrell among the fourteen black women journalists from the South (Wade-Gayles G., 1982). Yet, Mary Church Terrell penned a number of articles on race, women, suffrage, temperance, the involvement of black soldiers in the world conflicts and in peace. She wrote widely for the black press: The New York Age, The AME Review, The Voice of the Negro, The Crisis, The Southern Workman, Howard Magazine, The Baltimore Afro-American, The Indianapolis Freeman, The Chicago Defender, among many others. ${ }^{22}$ She also wrote for women's magazines, like The Women's Era, which when the NACW was set up, was renamed The National Association Notes and became the monthly newsletter of the organization, and The Aframerican Women's Journal, the organ of the National Congress of Negro Women (NCNW). She authored articles on prominent black intellectuals and role models, such as Frederick Douglass, "the greatest man this country has ever produced," Samuel Coleridge Taylor, Paul Laurence Dunbar, and Phillis Wheatley, "the genius of the race" (Jones B., 1990: 36). In this part, I will focus on four articles which demontrates how Mary Church Terrell relied on her experience and knowledge to articulate a more inclusive history, as a vehicle of self-esteem, and more specifically as a medium to reclaim black women's intellectual worth and respectability (Dagbovie P., 2004: 243).

Being a black woman trying to document and provide a counter-narrative of black life in America was not an easy task at a time when the profession was dominated by white 
men, and black men were trying hard to secure their own legitimacy within the field (Appleby J.O., et al., 1994: 52-53). Chapter 23 of Mary Church Terrell's autobiography is entirely devoted to the challenge of publishing her articles and short stories. Mary Church Terrell explains that her publishing experience was discouraging and disappointing as she firmly believed that her articles had been rejected because they broached the vexing race issue. She contends that her articles were controversial and that the United States was not ready to face up to the real picture of black life (Terrell M.C., 2005: 267). In addition, she explains that when she (a black woman) dares express it (her opinion), no matter how mild or tactful it may be, it is called 'propaganda,' or is labeled 'controversial' (Terrell M.C., 2005: 264). Consequently, Church Terrell refused to have her voice silenced and was a prolific writer. Therefore, as for many of her female contemporaries, like Ida B. Wells, the press was a vehicle through which she could challenge men's contempt of women's intellect. Her perseverance was symbolic of black women's reactions to the many significant forms of male exclusionary practices (Giddings P., 1984: 7). She was convinced that the press in general contributed to changing public attitudes and mentalities.

In a 1905 article entitled "The Mission of a Meddler" and published in The Voice of the Negro, Mary Church Terrell self-identified as a meddler, a word she applied to "everybody who has tried to advance the interests of the race by redressing wrongs" (Cooper B.C., 2017: 62). Such reflection led Mary Church Terrell to reach out to the white press with a dual objective: First, she hoped to fight racism by highlighting the tremendous strides accomplished by black Americans with a view to debunking the pervasive negative stereotyping of her race. Secondly, her articles in the white press sought to prompt interracial conversations and awaken white Americans' awareness to the harsh reality of black life in America.

Through perseverance and some helpful connections, she eventually succeeded in publishing a few articles in The Washington Post, The Washington Times, The Washington Evening Star and The Boston Globe. Her biggest victory, the thrill of her life according to her, was the publication of her article "Lynching from a Negro Point of View" in the June 1904 issue of The North American Review, a leading US white magazine of culture and opinion. Her article was a response to Nelson Page's January 1904 article in the same newspaper, "The Lynching of Negroes: its Causes and Prevention." ${ }^{23}$ The publication of her article, a remarkable achievement in itself, was the result of many concessions. First of all, she had to compromise on the title which was originally "Lynching from a Colored Woman's Point of View." As she suggests, "nobody wants to know a colored woman's opinion about her own status or that of her group" (Terrell M.C., 2005: 264). She secured the publication of the article thanks to the support of a friend, the American novelist and playwright W. Dean Howells (Terrell M.C., 2005: 265). In addition, in order to avoid antagonizing the editors and their white readers, she had to moderate her attack of Page who had presented a dramatized analysis of the lynching issue by focusing on the stereotype of bestial black male predators raping innocent white women. Her scathing arguments refuted each of Page's points, delineating the poisoned mentality of southern whites together with the true economic and social motivations behind "the ferocity and barbarity" of lynching which she referred to as "the aftermath of slavery." Furthermore, as she wanted to build her credibility without alienating the white national readership, she was forced to add elements about class bias in her narrative, acknowledging the reality of the rape issue by uneducated and poor black men. Following her first publication success with The 
North American Review, she attempted to submit "A Plea for the White South by a Colored Woman." It was refused by the editor who advised her to submit it to The Nineteenth Century and After, a British newspaper. To her surprise, it was accepted and published. In 1907, the British newspaper also accepted her article "Peonage in the United States: The Convict Lease System and the Chain Gangs," a groundbreaking reflection on the penal system. This article had been rejected by all the US magazines to which it had been sent. In the same year, she wrote an essay "What it Means to be Colored in the Capital of the United States" in The Independent, a New York based popular weekly magazine. ${ }^{24}$ The article was published anonymously. A handwritten copy of the original version was found in Mary Church Terrell's papers (Jones B.W., 1990: 32). In this radical essay, Mary Church Terrell recounts her everyday experiences as a colored woman facing the intolerable Jim Crow laws. She focuses on what she called the entrenched southern racist mentality of Washington D.C. by pinpointing the hypocrisy of American democracy through examples of the daily injustices the black community was subjected to in all walks of life "under the protection of the American flag." Washington is no longer "The Colored Man's Paradise," rather she states that "nowhere in the world do oppression and persecution based solely on the color of skin appear more hateful and hideous than in the capital of the United States." Mary Church Terrell's essays are political pamphlets calling for resistance and action, pushing for racial agitation and social change.

Another article illustrating her pragmatic reflections is "Please Stop Using the Word Negro" of which she published several versions over a period of twenty-two years in The Washington Post $(1927,1928,1949)$. This article is a provocative and innovative questioning of the terminology. She was one of the first intellectuals to challenge the term "Negro," a humiliating and degrading slave term which she believed should have been outlawed in the Emancipation Proclamation. Furthermore, she considers the word as a misnomer as it does not describe the "fifty-seven variety of complexions" of the black community and pushes for the word "colored people" instead. To corroborate her point, she argues that "When twenty or thirty of us are meeting together it would be as hard to find three or four of us with the same complexion...," implicitly pointing at the legacy of slavery and the sexual exploitation of black females. She finishes her article by praising the NAACP for having selected the word "colored people" in the name of their association. Another interesting aspect of this article is that Mary Church Terrell explains how her experience in Europe helped her define her identity. Indeed, while studying in Europe, she was introduced simply as an American, as someone coming from the United States. When people were puzzled about her color, she felt proud to mention her African ancestors. She would reply "I am an African American." Mary Church Terrell was ahead of her time in her use of this term. Lastly, she harshly condemns the journalists for using the degrading term of "Negress," an "ugly and repulsive word." Unquestionably, Mary Church Terrell's primary subject matter was the black woman in the United States, her condition and her representation.

In her 1905 article on lynching, Mary Church Terrell also highlighted the unpunished sexual exploitation that black women and girls had been enduring since slavery and were still experiencing as maids in white houses. Later in 1923, when the United Daughters of the Confederacy pushed for the building of a memorial honoring the black mammy, in Galveston, Texas, Mary Church Terrell voiced her fierce opposition in an editorial of the February 1923 issue of The Evening Star, a white Washington newspaper. She excoriated the Southern white women for their ongoing complicity in the sexual 
abuse of black women by white men, arguing that a memorial of this type was a hurtful reminder of slavery and white supremacy. ${ }^{25}$ Erecting such a memorial represented an insult to black women as it displayed the atrocities faced by the black mammy who was enslaved, had no home of her own, was the victim of white men's sexual violence and was forced to abandon her children. Such a stance demonstrates that Mary Church Terrell had insightful consideration of the significance of memorials as living tributes to the achievements of cultural icons, rather than as reminders of a cruel oppressive system of enslavement.

19 As a reaction to the "conspiracy of the silence" imposed on black women (Mc Henry E., 2007: 384, 395), Mary Church Terrell used her finely honed intellect to reflect creatively on the different functions of history. This led her to question the mainstream narrative of American history, and to push for new history concepts. She turned to the press as a bulwark against assertions of racial inferiority, while keeping women's history at center stage. Her autobiography, by presenting a critical account of the national history record, is the legacy of a black woman who succeeded in revising the mainstream narrative and questioning the authorship of black male intellectual historians.

\section{A self-published autobiography}

Undoubtedly, Mary Church Terrell's autobiography marks a shift in the tradition of African American autobiographical slave narratives. Yet, it is deeply rooted in a long tradition of black women's oral and written transmission practices (religious and public speeches, lectures, novels, poetry, scrapbooks...) which were tools of resistance against the silencing of their voices. Joanne Braxton argues that black women's autobiographies constitute "a tradition within the tradition" (Braxton J., 1989). What was Mary Church Terrell's primary objective when she undertook the writing of her autobiography at the age 62? As a woman leader and intellectual, Mary Church Terrell embarked on documenting her public life and opened a new era in what Cooper defines as "black women's leadership memoirs", which constitute alternative sites for early black women intellectuals to theorize their racial and gender identity, show their humanity, communicate their hopes for African Americans and share their legacies for future generations (Cooper B.C., 2017: 68). The writing of her autobiography was another personal attempt to overcome the denial of her theoretical writings. By writing her life story, she sought to use her lived experiences as lessons for future generations.

21 The original title of Mary Church Terrell's autobiography, A Mighty Rocky Road, epitomized the conditions of publication for a non-professional historian. As the final title A Colored Woman in a White World and the introduction of her autobiography suggest, Mary Church Terrell straightforwardly delineates the theoretical, intellectual and political framework of her work: "This is the story of a colored woman living in a white world. It cannot possibly be like the story written by a white woman. A white woman has only one handicap to overcome - that of sex. I have two - both sex and race. I belong to the only group in this country which has two huge obstacles to surmount. Colored men have only one - that of race" (Terrell M.C., 2005: 29). The title of her autobiography shows that her work incorporates a political dimension as Mary Church Terrell clearly asserts that she aims at disrupting the mainstream understanding of post-Reconstruction America. The first pages of the autobiography set the tone. In the 
first chapter, she tells us about her family background and in particular her grandmother Emmeline's personal story through a letter she received from a white man (the son of the grandmother's owner). She confronts the white man's view of the supposedly benevolent institution of slavery - "the affection which existed between Mother and Emmeline was more of the order of sisters than mistress and maid" - with her own reaction to the letter "There is no doubt that some slaveholders were kind to their slaves... But the anguish of one slave mother from whom her baby was snatched away outweighs all the kindness and goodness which were occasionally shown a fortunate, favored slave." (Terrell M.C., 2005: 34-35). In his review, Charles Wesley acknowledges that writing autobiographies is a way of writing history and argues that black male and female leaders who take the initiative of doing so are allies of history (Wesley C., 1941: 262). Terrell's own gendered interpretation of her family background challenges the canonical narrative of slavery and unearths a new page of American history. Through her many concrete examples, she renders invalid many of the generalizations about black men and women in American historiography (Guy-Sheftall B., 1992: 39). Like Anna Julia's Cooper in her 1892 A Voice from the South, she positions her work in a race and gender nexus, later coined the intersectionality concept (Crenshaw, K., 1989). She frames her narrative through her black woman's feminist perspective in order to give a truthful account of her life (Collins P.H., 2000). She traces her life from her early childhood days up to the late 1930s. As a black woman who lived in a white supremacist America, she used the narrative of her continuous exposure to an array of discriminatory practices (difficulty in securing a job in New York, buying a house in Washington D.C...) to demonstrate the harsh reality of colored people's lives in a supposedly free democracy. Most notably, throughout her autobiography, when she relates her train travel experiences as a child and later as a lecturer, she uncovers one of the most unique vulnerabilities of black women: the permanent threat to their personal safety and bodily integrity. This is the reality Mary Church Terrell wanted to transmit to white America, with the hope that they would question their flawed democracy. Conversely, as a woman leader, by writing her successful life story, she wanted to show the potential of black women intellectuals despite the many difficulties they faced.

If the completion of her memoirs had been an arduous task, the publication turned out to be even more challenging. It took her almost a decade to bring out the final version of her work. From the very beginning of the project, anticipating possible rejections, she contemplated writing anonymously. At the same time, drawing upon her "uplift" ideology and being used to the national spotlight (Evans S. Y., 2008: 64), she also found it essential to document her achievement as a woman race leader. She was aware of the significance of being a role model, of charting a plan of action for other black women and future generations. When she first contacted the editorial board of Little Brown \& Company, she shared her fears with the editor, Herbert F. Jenkins. Nevertheless, he encouraged her to start writing her story, to "present a penetrating and truthful picture of the experiences of a colored girl who achieved success despite the many obstacles." To attract a broad readership, the story had to be told simply and honestly. Jenkins did not ask her to sign a contract nor did he give her a word limit or deadline (Quigley J., 2016: 114, 118). Consequently, during the writing process, Mary Church Terrell had to make difficult choices in terms of rhetoric and tone: how could she give a true account of humiliations and injustices without showing too much resentment? She had to soften her bitterness and offer an optimistic outlook. Watson argues that the 
final drafts offer a more balanced assessment of her life, less confrontational, with the omissions of some controversies (Watson M., 1999: 111). Talking about Booker T. Washington, she admits that "He (Booker T. Washington) knew full well that I did not agree with some of his views, although I admired him greatly for the work he was doing in his effort to educate and uplift those representatives of his race who had so few and such meagre opportunities to develop themselves" (Terrell M.C., 2005: 231). She preferred to focus on her exemplary path, presenting herself as a precursor of the modern woman, capable of balancing her professional life as a black woman leader and spokeswoman and her role as a mother.

In spite of Jenkins's earlier encouragement, when she submitted her autobiography in March 1935 with a preface written by H.G. Wells, he refused to publish it. ${ }^{26} \mathrm{~A}$ month after she had submitted it, he sent her a letter explaining that he deemed the work interesting but far too long. She "simply had failed to tell her story in a manner that would captivate her readers and ensure its commercial viability" (Quigley J., 2016: 118). Although Little Brown \& Company's rejection could also have been influenced by the grim economic outlook with the Great Depression at its height, Mary Church Terrell remained convinced that the rejection of her manuscript was due to the controversial nature of her memoir.

Once more, she refused to give up. She wrote to her brother that she could never be comfortable until its publication (Jones B.W., 1990: 63). She asked for support and advice from Carrie Chapman Catt, a former suffragist and friend, and from Ralph Bunch, a political scientist at Howard University. Notwithstanding all of her efforts, her work was rejected by other publishers. Thereupon she resolved that she would publish her autobiography at her own expense with a vanity press, Ransdell Company of Washington D.C. She ended up marketing her autobiography by lecturing in several cities, and by writing to family members and friends. Over one thousand copies at $\$ 2.50$ dollars each were sold by 1942 . She never managed to find a publisher for a second edition.

H.G. Wells' preface and the review written by Charles Wesley, who was then Professor of History and Dean of the Graduate School at the history department of Howard University, are quite revealing about the lack of enthusiasm by publishers. Wesley posited that Terrell's enterprise was courageous, energetic and frank. Indeed, the autobiography, a voluminous 421-page book with 42 chapters, chronicles the key episodes of Mary Church Terrell's life, and conveys her thoughts and feelings on the complexity of race relations in America. H.G. Wells admitted that Terrell's autobiography was not a masterpiece, but for him, it represented a good exposé of the race conflict in America. He also challenged American readers to "turn over this plucky, distressful woman's naïve story of the broadening streak of violence, insult, and injustice in your country, through which she has been compelled to live her life" (Watson M., 1999: 83). ${ }^{27}$ The fact that no major newspaper like The New York Times or The Washington Post reviewed the work buttresses Mary Church Terrell's argument that white America was not ready to hear the opinion of a black woman.

Unquestionably, Mary Church Terrell's persistence in writing her memoir was due to the fact that it provided her with a kind of alternative space to perform her citizenship, a political site where she could promote a public agenda for racial advancement through the lens of her gender and race (Mostern K., 1999: 12). The mere fact that she gives interesting reflections on her encounters with prominent figures, white and black 
leaders, such as Jane Addams, Susan B. Anthony, and Frederick Douglass, demonstrates that she aimed at representing herself as their equal, implicitly giving herself a more central place within the national historical narrative. She shows deep admiration for Susan B. Anthony who she discovered during her college years. Susan B. Anthony became a friend and gave Mary Church Terrell the three volumes of her landmark account of the women's suffrage, The History of Women Suffrage. Mary Church Terrell explains that "I little dreamed that Fate would ever be kind enough so to order my life as to cause her (Susan B. Anthony) to invite me to be a guest in her home" (Terrell MC., 2005: 208). ${ }^{28}$ In chapter 19, Mary Church Terrell notes that her invitation at the $60^{\text {th }}$ celebration of the Seneca Falls Convention gave her the opportunity to remind her audience that "...the women of this country... should remember the great debt of gratitude they owe a colored man (Frederick Douglass) for the courage he displayed on a crucial occasion in their behalf when no other man was willing to come to their aid" (Terrell M.C., 2005: 209-210). Mary Church Terrell also recounts a 1921 controversy when a German propaganda campaign accused black American soldiers and African soldiers from French colonies of the sexual exploitation of German women. She refused to sign the petition framed by the WILPF (Women's International League for Peace) which called for the removal of the black troops. By letter, she warned Jane Addams that she would resign, arguing that she could not accept the distorted racial representation of black troops carrying out more sexual assaults than any other race of soldiers, and reminded her how women of her race "have been the victims of assaults committed upon them by men of all races." Following Terrell's appeal for racial justice, the petition was not processed (Terrell M.C., 2005: 408). The mere act of writing about her personal experiences and activism meant that Mary Church Terrell asserted herself as an independent woman on an equal footing with her black male and white female partners. More specifically, the narrative of her personal successes and achievement aimed at demonstrating the potential of race women as a whole, refuting the negative, limiting stereotypes that prevailed. Mary Church Terrell took a rocky road to legitimize black women's voices. Between 1968 and 2005, eight editions of Mary Church Terrell's autobiography were published. The 1968 edition was published by the National Association of the Colored Women's Clubs. Her autobiography remains a testimony of an American black woman and unearths a complete chapter of American history. It also gave a blueprint to the next generation of black women leaders like Angela Davis and Elaine Brown.

\section{Conclusion}

Since the last three decades of the twentieth century, African American women's history has become one of the fastest growing fields in American history (Dagbovie P., 2015: 54). The articles, essays, columns and autobiography written by Mary Church Terrell have contributed to its expansion. Mary Church Terrell's self-published autobiography is a trailblazing testimony of her struggle as a black woman in Jim Crow America. It was a truly unique achievement that few have equalled since. The fact that over one thousand copies were sold despite the extremely limited marketing and publication possibilities of the time is remarkable. We have to wonder whether the second edition she sought to have produced by a publishing company did not see the day because white publishers continued to find her evidence of deep, pervasive injustice unsettling. Her work remains a critical piece of evidence - both in its content 
and in the challenges surrounding its initial publication - which allows us to gain new insights into the harsh realities endured by African Americans, realities that failed to live up to the democratic ideals of the American republic. Since then, her re-published autobiography and recently re-discovered articles have prompted historical discussion on black women's lives and activism. Indeed, she continued her activism until her death and was instrumental in the fight for the desegregation of Washington D.C. restaurants and its landmark victory with the 1953 District of Columbia $v$ John C. Thompson Supreme Court decision, or in the Rosa Lee Ingram case - a black woman who was accused of murdering a white landowner - to quote just two examples. As an intellectual grassroots social activist, lecturer and journalist, Mary Church Terrell helped both to reconceptualize the conventional definition of what makes a historian and also what shapes black feminist identity consciousness. She transformed her double jeopardy, being black and being a woman, into creative sites. The legacy she left was her personal response to the erasure of black women from mainstream history and from the black-male centered narrative of African American history. She overcame multiple barriers and asserted her self-defined place in the profession as a popularizer of African American history. Her autobiography constituted a powerful means of reclaiming her activism and intellectual thought that she sought to leave as a legacy to future generations. In her 2020 Democratic Convention speech, Kamala Harris described herself as a testament to the dedication of generations of black women who inspired her. She listed Mary Church Terrell among these women who remained undeterred and fought for recognition. Because Mary Church Terrell dared to write and share her life story, she brought black women to the center stage in the $21^{\text {st }}$ century.

\section{BIBLIOGRAPHY}

Appleby, Joyce O., Lynn Hunt, and Margaret C. Jacob, Telling the Truth About History, New York, Norton, 1995.

Asukile, Thabiti, “Joel Augustus Rogers: Black International Journalism, Archival Research and Black Print Culture", The Journal of African American History, vol. 95, $\mathrm{n}^{\circ} 3-4$, summer-fall 2010, p. 322-347.

Bracey, John H. Jr., Meier, August, "Records of the National Association of Colored Women's Clubs, 1895-1992, part I”, Black Studies Research Sources, Research Collections of Women's Studies, Bethesda, Maryland, University Publications of America, 1994, p. 14, http://www.lexisnexis.com/ documents/academic/upa_cis/1555_RecsNatlAssocColWmsClubPt1.pdf, accessed January 16, 2020.

Braxton, Joanne M., Black Women Writing Autobiography: A Tradition Within A Tradition, Philadelphia, Temple University Press, 1989.

Broussard, Jinx C., Giving a Voice to the Voiceless: Four Black Women Journalists, 1890-1950, London, Routledge, 2003. 
Collins, Patricia Hill, Black Feminist Thought: Knowledge, Consciousness, and the Politics of Empowerment, Second Edition, New York and London, Routledge, 2000.

Cooper, Brittney C., Beyond Respectability: The Intellectual Thought of Race Women, Urbana Chicago, University of Illinois Press, 2017.

Crenshaw, Kimberle, "Demarginalizing the Intersection of Race and Sex: Black Feminist Critique of Antidiscrimination Doctrine, Feminist Theory and Antiracist Politics", University of Chicago Legal Forum, vol. 1989, Issue 1, p. 139-167.

Dagbovie, Pero G., "Black Women, Carter G. Woodson, and the Association for the Study of Negro Life and History, 1915-1950", The Journal of African American History, 88.1, 2003, p. 21-41.

Dagbovie, Pero G., "Black Women Historians from the Late 19th Century to the Dawning of the Civil Rights Movement", The Journal of African American History, 89.3, 2004, p. 241-261.

Dagbovie, Pero G., What Is African American History, Malden, Massachusetts, Polity Press, 2015. Des Jardins, Julie, Reclaiming the Past and Present: Women, Gender, Race and the Construction of Historical Memory in America, 1880-1945, PhD, Brown University, 2000.

Evans, Stephanie Y., Black Women in the Ivory Tower, 1850-1954: An Intellectual History, Gainesville, University Press of Florida, 2016.

Giddings, Paula, When and Where I Enter: The Impact of Black Women on Race and Sex in America, New York, HarperCollins Publishers, 1984.

Guy-Sheftall, Beverly, “Black Women's Studies: the Interface of Women's Studies and Black Studies", Philon, Spring 1992, p. 33-41.

Henry, Linda J., "Promoting Historical Consciousness: the Early Archives Committee of the National Council of Negro Women", Signs, vol. 7, n 1, Autumn 1981, p. 251-259.

Jones, Beverly W., "Mary Church Terrell and the National Association of Colored Women, 1896 to 1901", The Journal of Negro History, vol. 67, n 1, Spring 1982, p. 20-33.

Jones, Beverly W., Quest for Equality: The Life and Writings of Mary Eliza Church Terrell, 1863-1954, Brooklyn, New York, Carlson Publishers, 1990.

Logan, Rayford W., The Negro in American Life and Thought: The Nadir, 1877-1901, New York, Dial Press, 1954.

McHenry, Elizabeth, "Toward a History of Access: The Case of Mary Church Terrell," American Literary History, vol. 19, n² 2, July 2007, p. 381-401.

Miller, Sammy M. et al, “The Sixtieth Anniversary of The Journal of Negro History 1916-1976: Letters from Dr. Carter G. Woodson to Mrs. Mary Church Terrell," The Journal of Negro History, vol. 61, n 1, 1976, p. 1-6. JSTOR, www.jstor.org/stable/3031528. Accessed February 18. 2020.

Mostern, Kenneth, Autobiography and Black Identity Politics: Racialization in Twentieth-Century America, Cambridge, U.K, Cambridge University Press, 1999.

Parker, Allison, “When White Women Wanted a Monument to Black 'Mammies”, The New York Times, Sunday Review, February 6, 2020.

Quigley, Joan, Just Another Southern Town: Mary Church Terrell and the Struggle for Racial Justice in the Nation's Capital, New York, Oxford University Press, 2016.

Rief, Michelle, “Thinking Locally, Acting Globally: The International Agenda of African American Clubwomen, 1880-1940", The Journal of African American History, 89.3, 2004, p. 203-222. 
Terrell, Mary Church, "The duty of the National Association of Colored Women to the Race", in Published Speeches and Writings, 1888-1953, Alexandria, VA: Alexander Street Press, 2010, p. 340-354.

Terrell, Mary Church, “The Progress of Colored Women”, National American Women's Suffrage Association, Washington DC, February 1898.

Terrell, Mary Church, "Constitution of the International Council of Women of the Darker Races", Public Papers, Reel 14.

Terrell, Mary Church, "Lynching from a Negro's Point of View”, North American Review, vol. 178, n571, June 1904, p 853-868.

Terrell, Mary Church, "The Mission of Meddler", The Voice of the Negro, August 1905, p. 567.

Terrell, Mary Church, “A Plea for the White South by a Colored Woman”, Nineteenth Century, July 1906.

Terrell, Mary Church, "What it Means to Be Colored in the Capital of the United States", The Independent, vol. 62, n 3034, January 1907, p. 70-84.

Terrell, Mary Church, "Peonage in the United States: The Convict Lease System and the Chain Gangs", Nineteenth Century, August 1907, p. 306-322.

Terrell, Mary Church, "History of the High School for Negroes in Washington", The Journal of Negro History 2.3, 1917, p. 252-266.

Terrell, Mary Church, “The Black Mammy Monument”, The Evening Star, 1923.

Terrell, Mary Church, “Please Stop Using the Word "Negro, Letter to the Editor"”, The Washington Post, May 1949.

Terrell, Mary Church, A Colored Woman in a White World, Amherst, New York, Humanity Books, 2005, [Terrell, M.C., A Colored Woman in a White World, Washington DC, Ransdell Inc., 1940.

Wade-Gayles, Gloria, "Black Women Journalists in the South, 1880-1905: An Approach to the Study of Black Women's History," Callaloo, n 11-13, February 1981, p. 138-52.

Watson, Martha, Lives of Their Own: Rhetorical Dimensions in Autobiographies of Women Activists, Columbia, University of South Carolina Press, 1999.

Waters, Kristin and Conaway, Carol B., Black Women's Intellectual Traditions, Speaking Their Minds, Burlington, Vermont, University of Vermont Press, 2007.

Watson, Martha, "Mary Church Terrell vs Thomas Nelson Page: Gender, Race and Class in AntiLynching Rhetoric", Rhetoric \& Public Affairs, vol. 12, n 1, Michigan State University Press, April 2009, p. 65-89.

Wesley, Charles H., "Negro Autobiography and History, A Colored Woman in a White World by Mary Church Terrell and H.G. Wells", The Journal of Negro Education, April 1, 1941, p. 262-264.

Wilks, Jennifer M, “The French and Swiss Diaries of Mary Church Terrell, 1888-89: Introduction and Annotated Translation", Palimpsest: A Journal on Women, Gender, and the Black International, vol. $3 n^{\circ} 1,2014$, p. 8-32. 


\section{NOTES}

1. In her diary, she expressed her desire to honor her race by obeying God and doing works for the poor, the ignorant and the oppressed. She was sure that God would help her (Entry September 23, 1888). Religion was an omnipresent component in African American culture.

2. The original French version of Mary Church Terrell's diary has been digitized by the Library of Congress and can be accessed at https://crowd.loc.gov/campaigns/mary-church-terrelladvocate-for-african-americans-and-women/diaries-and-journals-1888-1951/mss425490001/ mss425490001-11/

3. Mary McLeod Bethune and Mabel K. Staupers were the only two women included in the anthology.

4. Her contemporary Anna Julia Cooper, who graduated from Oberlin in 1887, also taught at M. Street High School, the only black school in Washington at the time. Yet, Terrell never mentions Cooper in her autobiography.

5. She also travelled in Switzerland and Italy.

6. Married women were not allowed to teach, so she had to resign from her position.

7. Ida B. Wells (1862-1931) was an investigative journalist and the most prominent anti-lynching campaigner in the United States and abroad. She wrote many articles on the topic.

8. Mary Church Terrell taught English literature and German in night classes.

9. Josephine St. Pierre Ruffin also edited The Woman's Era, the first journal published by and for African American women.

10. Mary Church Terrell, "The duty of the National Association of Colored Women to the Race", in Published Speeches and Writings, 1888-1953 (Alexandria, VA: Alexander Street Press, 2010), 340-354.

11. Mary Church Terrell was also a charter member of the NAACP, the interracial organization launched in 1909 to fight segregation in courts following the 1908 Springfield riots. Langston Hughes, the black author and poet, contented that she was one of the most active volunteers in the Association during its formative years.

12. Mary Church Terrell managed astutely well in the controversy between Booker $T$. Washington and W.E.B. Du Bois. She admired Du Bois, "The High Priest of Higher Education." Yet as her husband's position depended a lot on his relationship with Washington, she became his ally by keeping him informed of the racial dissension within the NAACP.

13. Quoted in Jones B.W.; 1982, p. 28.

14. Mary Church Terrell uses upper case letters whenever she refers to the Race Problem in her autobiography.

15. Mary Church Terrell also addressed the International Assembly of the World Fellowship of Faiths in London in 1937.

16. Frederick Douglass was born in 1817 in Maryland to an enslaved mother and her owner. He was a fugitive slave, who, in 1845, published Narrative of the Life of Frederick Douglass, an American Slave: Written by Himself.

17. The ICWDR was launched in 1922 under the instigation of Margaret Murray Washington, Booker T. Washington's third wife, and operated until 1940. It was an elite organization whose membership was only open to women who had completed an outstanding piece of work. Mary Church Terrell Public Papers, Reel 14, Constitution of The International Council of Women of the Darker Races.

18. Carter G. Woodson (1875-1950) has often been called the father of black history; in 1915, he launched The Association for the Study of Negro Life and History (ASNLH) and The Journal of Negro History.

19. The feminist poet Alice Dunbar Nelson (1875-1935) was the other African American woman who early contributed to The Journal of Negro History (Dagbovie, P., 2003). 
20. Letters from Carter Woodson to Mary Church Terrell from May 1916 to September 1921.

21. Mary McLeod Bethune ((1875-1955) launched the National Congress of Negro Women (NCNW) in 1935 and was then its president. She envisioned the NCNW as a kind of clearing-house for all black women's organizations with a view to gaining more visibility and influence (Giddings, P., 1984, 212).

22. The Crisis was the official organ of the NAACP and Howard Magazine was published by Mary Church Terrell's brother.

23. Mary Church Terrell's article was published more than 9 years after Ida B. Wells's analysis of the lynching problem ("Red Record," 1895). Yet, both Ida B. Wells and Mary Church Terrell focused on the economics and power behind the lynching issue and discussed its sexual and gender dimensions.

24. She first delivered this essay in a speech before the United Women's Club of Washington, D.C., in October 1906.

25. For an updated analysis of the article, see Parker, A., 2020.

26. Mary Church Terrell had been acquainted with H.G. Wells for more than 25 years. She first met him and his wife in London on her return from the Peace Conference in Zurich. She telegraphed H.G. Wells a ten-page sample chapter and convinced him to write the preface of her book.

27. Part of the five-page preface by H.G. Wells was not included in the final introduction of Terrell's autobiography as some remarks were in fact condescending regarding Terrell's literary style. There was a positive review in The Christian Century which listed the autobiography as a book of value for Americans as a whole.

28. The centenary of the $19^{\text {th }}$ Amendment has prompted critical reflection of the Amendment. The new historiography of the women's suffrage movement gives a more inclusive account by bringing to light the long-neglected role played by African American women.

\section{ABSTRACTS}

This article seeks to render to Mary Church Terrell, one of the best educated black women leaders of her day, her long overdue recognition as a historian. It will demonstrate that Mary Church Terrell was a groundbreaking historian by bringing to light the stories and experiences of her marginalized community and in particular of black women's dual exclusion from American society. The first part of this article, an analysis of her life trajectory, will shed light on her understanding of the significance of making African American women's contributions more visible and part of both African American and women history. An overview at her career as a journalist, as both witness and actor, intellectual and social activist will then be carried out. For the purpose of this article, I will focus on four articles written by Mary Church Terrell which showcase her pragmatic approach to history. She aimed at presenting a new interpretation of salient issues of her time, such as lynching, from the perspective of a black woman. Finally, a special focus on her self-published autobiography, A Black Woman Living in a White World (1940), a detailed and compelling testimony of a black woman living in segregated America, will show that her pioneering and audacious endeavor was a successful attempt at moving black women to a central position in American historiography. 
Cet article cherche à réhabiliter la place de Mary Church Terrell, l'une des leaders africaines américaines la plus instruite de son époque, en tant qu'historienne légitime. Il démontrera que Mary Church Terrell fut une historienne pionnière en révélant les histoires et expériences de sa communauté marginalisée, et en particulier des femmes noires, doublement exclues de la société américaine. Dans une première partie, l'étude de sa trajectoire exceptionnelle nous permettra d'expliquer en quoi elle avait compris l'importance de rendre visibles les contributions des Africaines Américaines pour en faire des actrices clefs de l'histoire africaine américaine et de l'histoire des femmes. À partir de l'examen de quatre de ces articles, je reviendrai sur sa carrière de journaliste. Témoin et actrice de son époque, activiste et intellectuelle, elle adopta une approche pragmatique de l'histoire dans le but de donner une nouvelle interprétation des problèmes touchant sa communauté à partir de son propre point de vue de femme noire américaine. Son autobiographie, publiée à ses frais, A Black Woman Living in a White World (1940), est un témoignage vivant et précis de la réalité d'une Africaine Américaine dans l'Amérique ségréguée. Son entreprise audacieuse et pionnière a été une tentative réussie pour sortir des marges les Africaines Américaines et les placer au centre de l'historiographie américaine.

Este artículo busca rehabilitar como legítima historiadora a Mary Church Terrell, una de las líderes africanas más instruídas de su época. Se demostrará que Mary Church Terrell fue una historiadora pionera revelando historias y experiencias de su comunidad marginalizada, y en particular de mujeres negras, doblemente excluídas de la sociedad americana.

En una primera parte, el estudio de su trayectoria excepcional nos permitirá explicar cómo ella comprendió la importancia de hacer visibles las contribuciones de afro americanas para hacer de ellas actrices claves de su propia historia y de la historia de las mujeres en general. Después, a partir del examen de cuatro artículos suyos, analizaré su carrera de periodista. Fue testigo y actriz de su época, activista e intelectual, adoptó un enfoque pragmático de la historia con el fin de dar una nueva interpretación de los problemas que conciernen a su comunidad a partir de su propio punto de vista de mujer negra americana.

Por fin, me interesaré en su autobiografía, la cual, publicada con fondos propios, A Black Woman Living in de White Word (1940), es un vivo y preciso testimonio de la realidad de una afro americana en una América segregacionista. Su empresa pionera y audaz fue una tentativa exitosa de sacar de las márgenes en que se encontraban a los afro americanos y de situarlos en el centro de la historiografía americana.

INDEX

Palabras claves: historiografía afro americana, historia de mujeres, historiadores e historiadoras autoproclamados, autobiografías, publicaciones por cuenta del autor.

Keywords: African American historiography, women's history, self-proclaimed historians, autobiographies, self-publishing

Mots-clés: historiographie africaine américaine, histoire des femmes, historien.ne.s professionnel.le.s, autobiographies, publication à compte d'auteur

\section{AUTHOR}

\section{FATMA RAMDANI}

Fatma Ramdani est maîtresse de conférences à l'Université de Lille en histoire des États-Unis. Ses travaux portent sur les mouvements féministes américains dans leur dimension internationale. Elle s'intéresse à la contribution des Africaines-Américaines dans l'écriture de l'histoire. Ses 
travaux s'interrogent sur les questions de transmission et de mémoire. A titre d'exemple, a publié « Mary McLeod Bethune (1875-1955), historienne africaine américaine oubliée », dans Histoire en marges, Les périphéries de l'histoire globale, ed. Hélène Le Dantec-Lowry et al., Presses Universitaires François Rabelais, 2018. 